\title{
Observation and Analysis of the Peculiarities of English and Uzbek Detective Genre (in the Examples of J.H.Chase's Works)
}

\author{
Kholikova Nozima Nematilloyevna, Saidov Khayrulla Shavkatovich
}

\begin{abstract}
Observation of English modern detective genre and peculiarities of Uzbek detective genre is the main topic of this article. Comparative analysis of the Uzbek and English detective genres have been studied in the novels of James Hedley Chase and Uzbek translations of his works. Some similarities and differences between Uzbek and English detective genres have been shown in this paper.
\end{abstract}

Keywords: detective story, evidence, unexpected denouement, puzzle, superficially convincing, crime, private, defeat, opponents, murder, adventure.

\section{INTRODUCTION}

Detective literature is the most interesting and popular genre in which crimes are exposed in long and hard way. While this genre of literature varies in different countries, but their goals come to an end nearly the same. The translation of the aforementioned differences is still a problem in translation. If we look closely at the English and Uzbek detective literature and analyze them, we can clearly see the similarities and differences between them.

The traditional elements of English detective literature are: 1) visible perfect crime; 2) give testimony of the suspect of the wrong accused; 3 ) rioting of violent police; 4) great detective and surveillance forces; and 5) a surprising and unexpected denunciation of the investigator's criminal identity. ${ }^{1}$

Detective stories are often based on the principle that superficial, in some cases credible facts are ultimately irrelevant. The first English detective story was Edgar Allan Poe's "Murder on the Morgue Street", published in April 1841. Poet's French detective August Dupin, "Secrets of Marie Rochet" (1845) and "Choked Letters" (1845) appeared in the genre of storytelling then detective story quickly became the novel.

\section{LITERATURE REVIEW}

The mass production process in the late 1930s enriched the detective writers, among them Americans Erle

Revised Manuscript Received on July 22, 2019.

Kholikova Nozima Nematilloyevna, Teachers of Bukhara State University,Uzbekistan nozi0123@mail.ru

Saidov Khayrulla Shavkatovich, Teachers of Bukhara State University,Uzbekistan
Stanley Gardner, crime lawyer Perry Mason, and his disclosure of crimes in court; French and Richard Lockridge, another brilliant couple Mr. and Mrs. North. Sherlock Holmes made one of the most famous detectives. Other writers who spread the Holmes tradition or corrupted the new land include Nicholas Blake (alias C. Day-Lewis), Michael Innes, Dame Ngaio Marsh, Josephine Tee, Carter Dickson (John Dixon Carr) and P.D. James. After 1945, writer John le Carré adapted the detective's story format to a spy novel, in which he addressed the mysteries and character of the Cold War. Founded in 1945 to raise the standards of mystery writing, including a detective story, a professional organization, the American Mystery Writers, has made a significant impact on its annual excellence through the Edgar Allan Po Prize. Popular television programs have always used this format to pioneer detectives with a strict code of ethics, and solve the perfect problem of reporting the case. Many of the genre's scenes are searched from the outset by Edgar Allan Poe and discover the true Arthur Conan Doyle and Sherlock Holmes. The genre of detective fiction is characterized by distinct characters and themes and follows traditional forms.

James Hadley Chase (24 December 1906 - 6 February $1985)$ is an English writer. Although his original name was Renee Loj Brabazon Raymond, he was known for various pseudonyms like James Hedley Chase, James L. Docherty, Raymond Marshall, R. Raymond, and Ambros Grant. He was the most famous writer of all time. About 90 of Chase's novels have earned him the title of King of Writers in Europe. $\mathrm{He}$ is also one of the best-selling writers of international books.

\section{MATERIALS AND METHODS}

Comparative analysis of the Uzbek and English detective genres have been studied in the novels of James Hedley Chase and Uzbek translations of his works. Some similarities and differences between Uzbek and English detective genres have been shown with the help of comparative analysis method.

With the growing popularity of detective fantasy, its popularity in the genre of fiction came as the people moved to big cities and interacted with other people in all areas of life. This mass migration in big cities was not a crime, and a whole part of people's lives, but, like in the big city, violations, looting, bigotry and other crimes were commonplace. People were stunned and scared of crime,

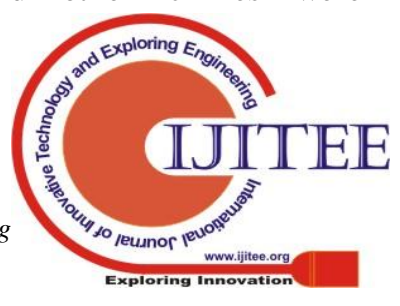




\section{Observation and Analysis of the Peculiarities of English and Uzbek Detective Genre (in the Examples of J.H.Chase's Works)}

which made it a perfect theme for recreational use.

The detective genre is a story that mixes with the Gothic genre, and that fusion focuses on dark elements, bad motives, and unexpected or brilliant solutions.

What does an English detective mean? Initial detective protagonists were generally professional private detectives; later stories tell detectives of all shapes and sizes, crime witnesses, ordinary people, insurance investigators and more. Most investigators have the following characteristics:

- It is comparable to mythological heroes (for example, Odysseus) because they represent difficulties, temptations, threats, and are usually adhered to high power (usually true)

- Known as "eyes", "seeing everything"

- Usually well-educated and sophisticated, sometimes rich

- He had physical strength and courage

- Have average speed or agility in card playing, shooting, car racing, and so on.

- They often defeat their opponents with their tongue, rather than their usual rival power

- Usually, you are asked to restore something: an object, a person, or peace

The English literature contains a detective code which is expected to be a high code of conduct for all investigators. It usually encourages her to choose what she calls the "right thing to do." Some aspects of this code:

- Closed and anonymous; away from privacy and publicity or fame

- Commitment to a partner and profession

- customer dedication

- economic relationship with client money

- Collaborates with police on a level, but its investigation overrides the law (customer dedication comes first)

- Prohibits learning of all possibilities and cheating

Common topics in English detective fiction:

Here are some common and open themes that are common in most detective fiction stories:

- Search for something that looks invisible but not trivial

- Exact crime identified as a repetition of previous crimes

- Family rich with problems or privacy

- Clean up the corrupt city or system

- An antagonist with double detection

Bad image

- Certain personalized villain • Innocent class (i.e. gangsters) Fatale

- Irresistibly attractive woman who leads men into danger

- Detective's love interest

- Could be the cause of the crime, and so the detective must ultimately reject her

Client
- The person who comes to the detective for help

- Lays out all the clues and explains who is involved The Villain

- A specific, individualized bad guy

- A culpable class (i.e., mobsters)

The genre of detective fiction can be divided into two classes: formal (English) and intense (American). The fierce, sturdy detective fiction genre is appealing to Americans, combining realism with humor. The fictional detective fantasy is represented by strange, angry stories about violence, corruption. This detective story usually takes place in the city, and the detective himself becomes the opposite of society.

\section{DISCUSSION}

In Uzbek literature, however, some literary critics view the literature as merely the direction in which the "digestible" works are composed of gestures. However, there are a number of invaluable works that prove that this is not true, and that is not only a specimen of detective literature, it also promotes deeper philosophical ideas.

You can read a number of works by $\mathrm{H}$. Tuhtabaev, "Shaytanat" by Tahir Malik or "King" by Said Ravshan. You cannot say, "Their lives are short and will soon be forgotten. Some have been living for ten, twenty years, and some half a century." In addition to enjoying the reader, it also provides spiritual and spiritual nourishment."

In an interview with writer and literary scholar U. Khamdam, "Literature is a sacred place..." the artist emphasized that "the first elements of detective literature appear in folklore," and "in the next stage A. Kadyiy brought the detective elements to folklore. created a great work of the past.

So, detective literature is not an event that happened yesterday or today. In the works of our ancestors, whose level of thought is not less than that of the West, some of them tell their first impressions of the process of searching and punishing sinners in fairy tales and fairy tales. In many fairy tales, such as the Alpomish, the Sunderland, the Ravshan, and the Three Boots, the heroes fight against injustice and evil. Let's look at the fragments with the detective elements in the Alpomish poem: "Alpomish, after getting out of the prison of the king of the country of Calvary, after finding him with Kultouy, says," Well, grandfather, what's in the country? " Qultay says: "Ultra-hummingbird is going to bed and trying to marry his wife. You will go and kill ... "Then Alpomish said," Grandpa, be me, and I will be with you. Who is the friend, and who the enemy will see with my own eyes? 'Do not let anyone slip and die." ${ }^{, 3}$ Following this advice, the two are dressed in each other's clothes and enter the wedding without anyone ever thinking.

Hakimbek's intention is reminiscent of the plan. Based on the fact that the detective was the main character of the detective and could not be seen as a criminal until the plan

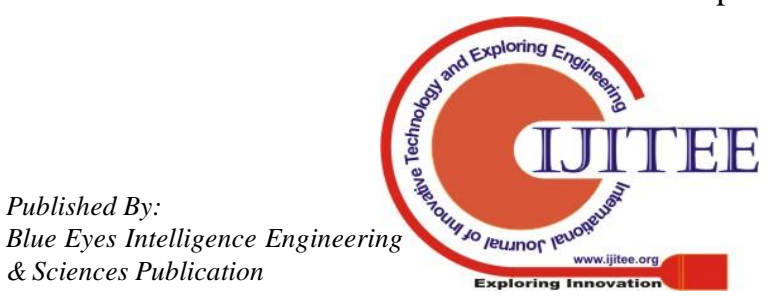


was implemented, we were convinced that the poem contained elements of the detective. Especially in this passage we find phrases that are based on the idea that the detective's main purpose is to seek the truth. In other words, "Alpomish" does not pretend to be someone else, so that no one can fall on his heel and get justice. When he returns to his home in the form of a Kultai, the misfortune of seeing his family in disarray is discouraged. That is, when they saw their sister, who was caring for her husband in the field, her mother, who cleaned the hoofs on the ditch, her father, who was carrying water in the water, Yodgor, his only child who was humiliated by the tyrants, and Barchinoy. He wants to help. But even in such situations, he shows his own determination and restraint. He remembers that he had to do something secret to reveal the truth.

Thousands of years ago, detective and detective elements were also present. Throughout our research, we have observed that detective elements can be found even in the classical literature. There are also detective elements in the poems by Alisher Navoi Khamsa. We have seen that these elements were also used in the fourth book of the Khamsa, the Seven Planet. In the story of Jabir, Suhayl and Mehr, a traveler from Fifth Climate, Jabir is described as a criminal, Mehr is a victim, and Suhayl is a detective. Jabir captures people with all sorts of tricks, and his name means "victim, oppressor." Of course, Alisher Navoi did not intend to create a detective work. He wanted to say that no crime in the world will go unpunished.

Uzbek detective works have a trio as well as many fiction. But this trio is not a love triangle, but a criminal-victim-detective, and in some cases, the victim is not involved at all, and the detective-criminals act as police officers. Jobir - Mehr - The Suhayl trio is an example of the first type of action. This is because events start with Mehr's secret capture. Evidently, Mehr became a victim. Suhayl has become a savior of justice and a detective.

Typically, an interrogator can be recruited by different people: law enforcement officers, hired detectives, relatives, friends, victim acquaintances, and sometimes completely unknown people. Navoi was very attentive to Suhayl as both a relative and victim's friend and friend. Consequently, along with folklore, our classical works played an important role in the formation of the Uzbek national detective.

Indeed, humanity has been created, along with goodness and kindness, the existence of such evils as wickedness and crime, but not so much as in recent times. In the next stage, A. Kadiri skillfully introduced the detective elements of the oral work to the creation of a great literary memorial, "The Days," which still amazes scientists. Otabek's meticulous efforts to expose Homid's crimes in the work remind the world of detective literature. It was decades before the very first detective was created with this work.

There were no works in this direction until A. Kadyri's. In the early 60's, that silent volcano erupted, that is, the story of Iskandar Kalandarov, "Witness, on the leaf ...". This work is one of the first attempts in the new genre. The author tells an interesting story of what he has seen and heard, and how he works with police officers in finding the courage, commitment to their work, and fraud, and other serious crimes. But the work is not artistic.
In the 1970s, such spirit works by one of the authors, Ulmas Umarbekov, who "felt more responsible for this genre" (Y. Solijonov), contributed to the development of the genre. As Uzbek people's writer Tahir Malik acknowledges, "It is worth noting that Umarbekov is one of the founders of modern Uzbek detective literature." The first scene of the immortal brother's performance at the Kokand Theater was "Court," "The Summer Rain" was one of the first pieces of modern detective writing."

Yes, he is. These works by Umarbekov have made a significant contribution to the formation of the detective genre in Uzbek literature. The author's novel "Fatima and Zuhra" also led the detective elements. The author also introduced the image of the Uzbek detective detective in the world.

Because at that time in the world of detective literature, the adventurers were male. Given that detective is the first feature of the detective's work, Zuhra even exposes a number of crimes that police officers have to uncover. So he is a detective. In creating the image of a scout woman, the writer has made a tremendous breakthrough over the national boundaries. Another writer, Tohir Malik, who later felt responsible for this genre, said that a genuine Uzbek national detective had been created. In this work we can see in detail the characteristics of the detective literature, that is, Asadbek's life and work in the criminal world are detailed in various ways. The writer also describes the horror of the crime scene and the difficulties it has uncovered. Asadbek, the author, not only shows the true nature of evil, but also reveals that the emergence of this evil can occur beyond the will of man, intentionally, and has deep social and moral roots. Asadbek was also investigated for his life-long crimes.

Writers such as O. Mukhtar and H. Dostmuhammad have also done well in this direction. However, as Y. Salijonov stated, "... the works of adventure, the detective have become more numerous. However, two-thirds do not meet the requirements of this genre. While responsible writers have created the work flawlessly for months and years, "masterful writers are desperate to write such works." Recent detective writers first investigate the genre's requirements and then write it down, and it would be appropriate to avoid such objections.

\section{CONCLUSION}

To sum up, detective elements in the Uzbek literature have long since come to prominence, despite the serious obstacles to their formation as genres because of the prohibition of social and political order in the creation of detective works in the 20th century. Uzbek detective literature has also proven that it has a high artistic value and that it can produce works that meet the requirements. 


\section{REFERENCES}

1. Alpomish. Sharq. - T.: 1998. 231-bet

2. I. Qalandarov. Shohidamas, bargida... O‘Zadabiynashr - T.: 1962.

3. O‘. Umarbekov. Tanlangan asarlar. 1-jild. Sharq. - T.: 2002. 11-bet

4. T. Malik. Shaytanat. Sharq. - T.: 2006.

5. T. Malik. Qiyomat qarz. Sharq. - T.: 2007.

6. "O'zbekiston adabiyoti va san'ati” gazetasi. 2007 yil, 2-son.

7. Chase J.H. The vulture is a patient bird. Royallib.ru. p-3

8. Чейз Ж.Х. Кузгун сабрли куш. Тошкент-“О’zbekiston”, 2012. b-8 